\title{
Maternal lead acetate exposure during lactation persistently impairs testicular development in male offspring of swiss albino mice.
}

\author{
Dr.Durgesh Nandini Sharma \\ Endocrinology and Physiology Unit, School of Studies in Zoology and Biotechnology, \\ Vikram University, Ujjain, M.P., India
}

\begin{abstract}
Lead Is One Of The Oldest Known And Most Widely Studied Occupational And Environmental Toxicant. Lead Compounds Are Known To Adversely Affect The Various Mammalian Systems. Reproductive Toxicity, Which Can Be Defined As The Adverse Effect Of Chemicals, Lead Being One That Can Affect The Gonodal Structure And Functions, Can Cause Alterations In Fertility And Impaired Gamete Function. Present Study Aims To Investigate The Effects Of Maternal Lead Acetate Exposure During Lactation On Postpartum Development Of Testes In Offspring Mice. During Experimental Period, Lactating Female Mice Was Given Lead Acetate (0.5ml/Day) From Day 1 To Day 21 Of Lactation. The Results Indicated That Exposure Of Lead Caused Histological Alteration In Developing Testes Of Mice And Significantly Alters The Density Of Inter Tubular Cellular Elements. In Present Investigation It Is Observed That Lead Toxicity Caused Decreased Testicular Weight Of Developing Pups In Experimental Groups As Compared To Control Pups. We Can Conclude From Our Findings That Lead Acetate Administrated During Lactation Adversely Affects Developing Testis Of Swiss Mice.
\end{abstract}

Keywords: Development, Histology, Lactation, Lead Toxicity, Swiss Mice, Testis.

\section{INTRODUCTION}

The humans are exposed to various types of environmental contaminants at different stages of their life span, majority of them are harmful. Exposure of heavy metals during early age of life has been associated with adverse effects on development of gonads. Age dependent alterations in developing reproductive tract sensitivity to other toxicants including metals may also occur. Possible mechanisms for altered resistance of the pre-pubertal gonad may reside in a decreased rate as gonadal cell proliferation [1] or alterations in the distribution of the toxicant to gonadal cells [2,3]. The oldest harmful agent known to mankind is lead. Lead is of public health concern due to their toxic effects on various developing organs, persistence in pregnant and breast feeding mothers. The role of lead in male sub fertility factor is of particular current interest [4]. In men, especially in professional workers, lead exposure results in infertility and sterility [5], testicular atrophy, cellular degeneration, and reductions in seminiferous tubule diameter and sperm count, depending on the dose and time of exposure [6]. In animal models, lead exposure consistently decreases male reproductive function at the level of the hypothalamic-pituitary-testicular axis [7]. The effects of lead on adult rat testis have been widely studied and observations demonstrate that lead in particular alters those organs, as evidenced by testicular necrosis and atrophy in rodents [8]. Once the lead is in the bloodstream, it is distributed into soft and hard tissues [9]. Milk is the most important food source for newborn, however, also is a pathway of maternal excretion of toxic elements such as lead, and these toxins impact most severely on the newborn at a time of rapid development of the central nervous system [10], since neonates absorb 40-50 times more lead than adults [11]. It appears from the evidences that the neonatal period is a critical stage in the process of sexual development and maturation in primates [12]. Keeping the above information in mind, present study was undertaken to investigate the effects of maternal lead exposure during lactation on postpartum development of testis in offspring mice.

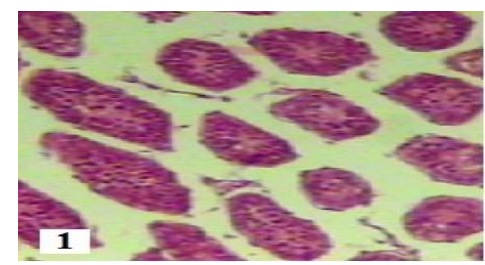

Fig. 1 Control group (7 days old mice testis) showing developing seminiferous tubules with many Spermatogenic cells. 


\section{MATERIALS AND METHODS}

Forty two young healthy and sexually mature female Swiss albino mice (Musculus albinus) were used in present study. The mice were procured from Veterinary College, Mhow (M.P.). These were maintained under identical laboratory conditions. Two female mice were paired overnight with one male. The onset of pregnancy (day 1) was considered to be the first morning when a vaginal plug was observed. The normal females were allowed to deliver their offsprings naturally. All lactating females were randomized into two groups (control and treated). At parturition (day 0 lactation) the lactating females of treated group were administered with $0.5 \mathrm{ml} / \mathrm{day}$ Of $0.5 \mathrm{ppm}$ aqueous lead acetate for a period of 7, 14 and 21 days of lactation. Infants of both the groups of mice (control and treated) were sacrificed, testis dissected out and immediately fixed in Bouins's fluid. After 24 hours, the testis were washed, dehydrated in graded series of alcohol, cleared in xylene and embedded in paraffin wax. The serial sections cut at $5 \mathrm{~m} \mu$ were stained with haematoxylin and Eosin for studying histological alterations.

\subsection{Morphometric study}

Quantitative analysis of developing spermatogenic cells and sertoli cells were carried out from 10 perfect transversely cut tubules from each testis of respective groups. The relative number of different cellular elements per tubular cross section were quantified at 1000X magnification [13]. Seminiferous tubular diameter was determined at 400X magnification by ocular micrometer and Leydig cell population was analyzed per square $\mathrm{cm}$ area from sagital plane area of the section at same magnification.

\subsection{Statistical analysis}

The data were expressed in Mean \pm SEM and were evaluated for statistical significance with the student "t" test.

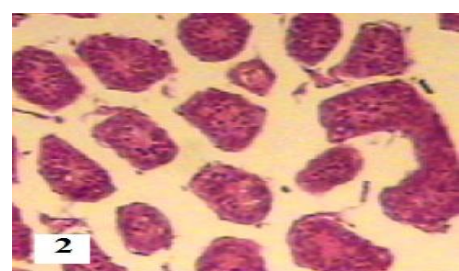

Fig. 2 Treated group (7 days old mice testis) Exhibiting less affected developing seminiferous tubules.

\section{RESULTS}

\subsection{Days 7 post partum}

In present investigation control testis of 7 days old mice showed well developed seminiferous tubules and regular distribution of cells. Sertoli cells were located near the basement membrane of the seminiferous epithelium and spermatogonia cells were also located and arranged in layers with round shape and surrounded by single germ layer. At day 7 post partum there was distinct lumen visible in the centre of the tubules (Fig.1). The regular shape of seminiferous tubules and their arrangements were almost similar in treated group at 1 st week of the developing period. Some cells of the seminiferous tubules showed pycknotic nuclei. Spermatogonia which were embedded at the side margins of sertoli cells got detached from these cells and scattered all around and inside the developing seminiferous tubules (Fig.2). Maternal lead exposure during lactation, the number of sertoli cells, leydig cells, spermatogenic cells, testicular weight, thickness of tunica albuginea and diameter of seminiferous tubules were not significantly decreased (Table 1).

\subsection{Days 14 post partum}

During this period the developing testes of the controls exhibited normal appearance of seminiferous tubules and developing germ cells inside them (Fig.3). While in treated group the testes showed more drastic changes. Lead acetate affected the developing seminiferous tubules and changed their shape and size and large vacuole was visible near the tunica albuginea in comparison to control. Sertoli cells became shrinked and large number of developing germ cells exhibited degenerative changes characterized by pyknotic nuclei (Fig.4). The cellular elements of the tubuls, testicular weight, thickness of tunical albuginea and diameter of seminiferous tubules were significantly $(\mathrm{P}<0.05)$ decreased in lead treated group (Table 2$)$.

\subsection{Days 21 post partum}

On 21st day, the testis in control mice reveals that it consists of seminiferous tubules and inter tubular elements. Each seminiferous tubule consists of the tubular wall with outer most basement membrane. Resting on the basement membrane are the spermatogonia and the sertoli cells. The spermatogonia, intermediate spermatogonia and primary spermatocytes in various phases of development were observed (Fig.5). While in treated group revealed remarkable damage in its histomorphology in comparison to control. The seminiferous tubules were disorganized and tunica albuginea was broken at several places. The spermatogonia were deformed and the cytoplasm becomes vacuolated and granular. Many spermotocytes showed pycknotic nuclei and faintly stained cytoplasm (apoptotic). Degenerative changes were also seen in the Sertoli and Leydig cells (Fig.6). The density of inter tubular elements, testicular weight, thickness of tunical albuginea and diameter of seminiferous tubules were significantly $(\mathrm{P}<0.001)$ decreased in lead treated group (Table 3$)$. 


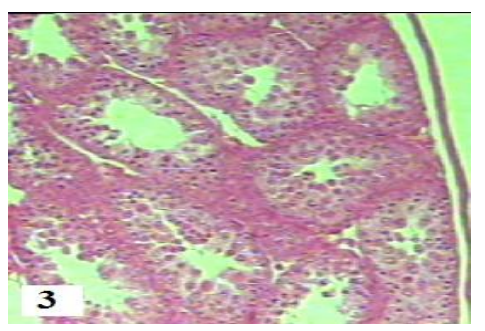

Fig. 3 Control group (14 days old mice testis) showing normal appearance of seminiferous tubules with developing germ cells inside them.

\section{DISCUSSION}

Increasing evidence demonstrated that lead could be transported from dams to pups through milk $[14,15]$. The present study on developing testis showed that Lead altered the regular shape of seminiferous tubules and their arrangements. Lead reduced the germ cells and spermatogonia and disarranged their distribution in seminiferous tubules. The developing seminiferous tubules and their shape and size also decreased by lead acetate. These results suggest that lead exposed through drinking water during lactation could be transported from dams to pups through milk. The histological results revealed a degeneration of germinal epithelium with sloughing of germ cells into the lumen of seminiferous tubules [16]. Atrophication of seminiferous tubules and the number of Leydig cells appeared to be lower in lead treated group [17]. Many studies previously by other researchers have also shown the reduction of germinal epithelium which was seems to be due to damage of germinal cells [18]. Loss of germinal epithelium cells [19] and effects were reflected in the reduction of the thickness of epithelium and seminiferous tubule diameter (STD) as a consequence of the action of lead in the reduction in numbers of prospermatogonia and spermatocytes [20]. It is known that the phase of spermatogenesis are negatively affected by several factors including pollutants such as lead [21]. Lead acetate may inhibit spermatogenesis by a disturbance of metabolic activity of the Sertoli cells [22] and lead decreased sperm count, motility and increased morphological abnormalities in animals [23,24]. Several previous studies demonstrate that maternal lead exposure during lactation delayed the timing of puberty in female offspring [25]. Abnormal Leydig cell aggregation in the fetal testes of rats exposed to phthalates was associated with the decreased $\mathrm{T}$ synthesis in testes [26]. Thus, maternal lead exposure during lactation can impair testicular development in male offspring is of great interest. The present results showed that the testicular weight and number of inter tubular cellular elements were significantly decreased in pups whose mothers were exposed to lead during lactation.

In summary, the present results allow us to reach the following conclusions. First, lead could be transported from dams to pups through milk; second, neonatal lead exposure through milk persistently disrupts testicular development. Moreover, the histological modification in the basic precursor of gonads during the post partum development causes reduced fertility in adulthood in male. This might be characterized to abnormal development or dysfunction of sertoli cells and the all cells which are responsible for providing normal environment of the germ cell proliferation and maturation in males.

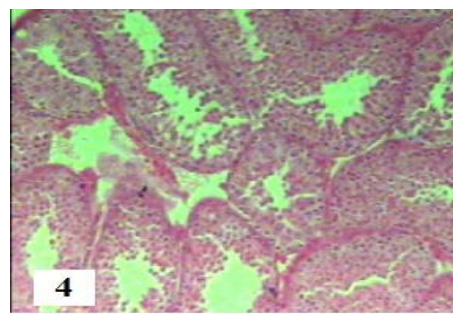

Fig. 4 Treated group (14 days old mice testis) showing irregular shape of seminiferous tubules with degenerative changes in germ cells.

\section{ACKNOWLEDGEMENT}

Author is thankful to Dr. S.C. Kothari, Professor and Head School of Studies in Zoology and Biotechnology, Vikram University, Ujjain (M.P.), for providing necessary laboratory facilities during this investigation 


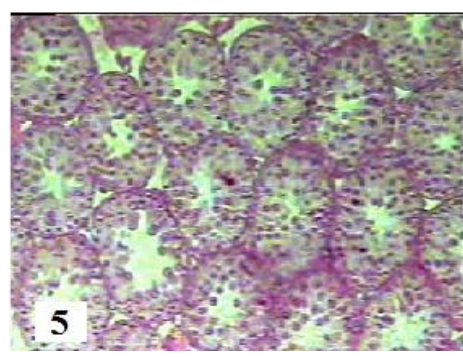

Fig. 5 Control group (21 days old mice testis) Exhibiting compact appearance of seniferous tubules with many newly form spermatogenic cells.

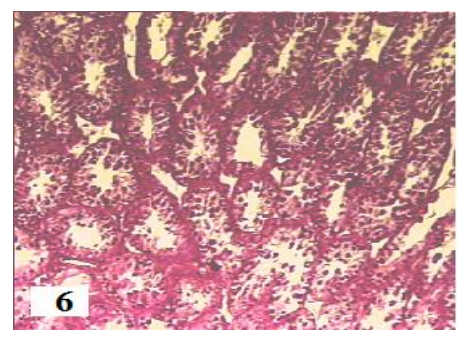

Fig. 6 Treated group (21 days old mice testis) Exhibiting damage seminiferou tubules, many Spermatogonia with pycknotic nuclei and damage sertoli cells due to toxic load of lead.

Table 1: Effect of lead acetate on testicular elements on 7 days post partum period of mice.

\begin{tabular}{|c|c|c|}
\hline Parameter & Control & Treated \\
\hline Testes weight (g) & $0.8+0.0007$ & $0.8+0.0009^{\mathrm{NS}}$ \\
\hline $\begin{array}{l}\text { Density of sertoli cell } \\
\text { (number per seminiferous } \\
\text { Tubule) }\end{array}$ & $7.02 \pm 2.01$ & $8.03 \pm 1.20{ }^{\mathrm{NS}}$ \\
\hline $\begin{array}{l}\text { Density of spermatogenic cell } \\
\text { (number per seminiferous } \\
\text { tubule) }\end{array}$ & $50.13 \pm 25.18$ & $48.15 \pm 35.02^{\mathrm{NS}}$ \\
\hline $\begin{array}{l}\text { Density of leydig cell } \\
\text { (number/mm2) }\end{array}$ & $5.14 \pm 13.11$ & $5.19 \pm 1.22^{\mathrm{NS}}$ \\
\hline $\begin{array}{l}\text { Thickness of germinal } \\
\text { epithelium }(\mu \mathrm{m})\end{array}$ & $35.06 \pm 17.21$ & $37.03 \pm 18.3^{\mathrm{NS}}$ \\
\hline $\begin{array}{l}\text { Diameter of seminiferous } \\
\text { tubule }(\mu \mathrm{m})\end{array}$ & $10.50 \pm 0.19$ & $10.78 \pm 0.22^{\mathrm{NS}}$ \\
\hline
\end{tabular}

All values are expressed in \pm SEM Significant level, $\mathbf{N S}=$ Non significant

Table 2: Effect of lead acetate on testicular elements on 14 days post partum period of mice.

\begin{tabular}{|c|c|c|}
\hline Parameter & Control & Treated \\
\hline Testes weight & $0.14 \pm 0.0019$ & $0.13+0.0008 *$ \\
\hline Density of sertoli cell (number per seminiferousTubule) & $10.02 \pm 2.01$ & $7.03 \pm 1.20 * *$ \\
\hline $\begin{array}{l}\text { Density of spermatogenic cell (number per seminiferous } \\
\text { tubule) }\end{array}$ & $90.13 \pm 25.18$ & $82.15 \pm 35.02 * *$ \\
\hline Density of leydig cell (number/mm2) & $11.14 \pm 13.11$ & $9.19 \pm 1.22 * *$ \\
\hline Thickness of germinal epithelium $(\mu \mathrm{m})$ & $65.06 \pm 17.21$ & $50.03 \pm 18.3 * *$ \\
\hline Diameter of seminiferous tubule $(\mu \mathrm{m}$ & $13.5 \pm 0.02$ & $12.7+0.052 *$ \\
\hline
\end{tabular}

All values are expressed in \pm SEM

Significant level, NS $=$ Non significant, $*=(\mathbf{P}<0.05), * *=(\mathbf{P}<0.01) * * *(P<0.001)$ 
Maternal lead acetate exposure during lactation persistently...

Table 3: Effect of lead acetate on testicular elements on 21 days post partum period of mice.

\begin{tabular}{|c|c|c|}
\hline Parameter & Control & Treated \\
\hline Testes weight & $0.18 \pm 0.0021$ & $0.14 \pm 0.0018 * * *$ \\
\hline Density of sertoli cell (number per seminiferous Tubule) & 13.04+3.01 & $7.03+1.20 * * *$ \\
\hline $\begin{array}{l}\text { Density of spermatogenic cell (number per seminiferous } \\
\text { tubule) }\end{array}$ & $120.15 \pm 22.18$ & $89.19+55.02 * * * *$ \\
\hline Density of leydig cell (number/mm2) & $15.14+13.11$ & $9.25+2.33 * * *$ \\
\hline Thickness of germinal epithelium $(\mu \mathrm{m})$ & $75.08+19.21$ & $55.03 \pm 18.3 * * *$ \\
\hline Diameter of seminiferous tubule $(\mu \mathrm{m}$ & $16.5 \pm 0.02$ & $12.7 \pm 0.052 * * *$ \\
\hline
\end{tabular}

All values are expressed in \pm SEM

Significant level, NS $=$ Non significant, $*=(\mathbf{P}<0.05), * *=(\mathbf{P}<0.01) * * *(\mathbf{P}<0.001)$

\section{RERERENCES}

[1].

[2].

[3].

[6].

[10].

[12].

DR. Mattison, Drugs, Xenobiotics and the Adolescent: Implications for Reproduction. In DrirgAfetabolisrii in The Immatirre Human, LF Soyka and GP Redmond (eds). Raven Press, New York, 1981, pp. 129- 143.

AD. Johnson, WR. Gomes, and NL. Vandemark, The Testis New York. Academic Press., 10:1970, 483-554. volume. And the Flow of Lymph and Blood in the Testis of Rats. J. Etidocririol.91: 1981, 245-254.

WY. Wong, CMG. Thomas, JMWM. Merkus, GA. Zielhuis, RMP. Steegers-Theunissen, Male factor subfertility: possible causes and the impact of nutritional factor. Fertil Steril 73: 2000, 435-442.

MR. Cullen, RD. Kayne, JM. Robins, Endocrine and reproductive dysfunction in men associated with occupational inorganic lead intoxication. Arch Environ Health 39:1984, 431-440.

WG. Foster, A. McMahon, EV. Younglai , EG. Hughes, EC. Rice, Reproductive endocrine effects of chronic lead exposure in the male cynomolgus monkey. Reprod Toxicol 7: 1993, 203-209.

RZ. Sokol, Hormonal effects of lead acetate in the male rat: mechanism of action. Biol Reprod 37: 1987, $1135-1138$.

RF. McGivern, RZ. Sokol, NG. Berman, Prenatal lead exposure in the rat during the third week of gestation: Long-term behavioral, physiological, and anatomical effects associated with reproduction. Toxicol Appl Pharmacol 110: 1991, $206-215$.

L. Gerhardsson, V. Endlyst, V. Lndlyt, N. Lundstrom, Lead in tissues of decrease lead smelter workers. J Trace Elem Med Biol. 9: $1995,236-143$.

A. Astrup-Jensen, SA. Slarach, eds. Chemical contamination in human breast milk. Boston Rouge, LA:CRC Press 1991.

I. Corpas, M.Castillo, D. Marquina, MJ.Benito, Lead intoxication in gestational and lactation periods alters the development of male reproductive organs . Ecotoxicol Environ Saf 53: 2002, 259-266.

DR. Mann, HM. Frase, The neonatal period: a critical interval in male primate development. J Endocinol 149: 1996, $191-197$.

CP. Leblond, and Y. Clarmont, Differentiation of stages of the cycle of seminiferous epithelium. Ann N Y Acad Sci 55: 1952, $548-573$.

IP. Hallen, L.Jorhem, A. Oskarsson, 1995. Placental and lactational transfer

of lead in rats: a study on the lactational process and effects on offspring. Arch. Toxicol. 69: 1995, 596-602.

IP. Hallen and A. Oskarsson, 1993. Dose dependent transfer of 203lead to milk and tissue uptake in suckling offspring studied in rats and mice. Pharmacol. Toxicol. 73: 1993, 174-179.

Yasser Said El-Sayeda and Mahmoud Shaban El-Neweshy, Impact of Lead Toxicity on Male Rat Reproduction at Hormonal and Histopathological Levels. Toxicological \& Environmental Chemistry., 92: 2010, 765-774.

Shan, T. Tang, and X. Zhang, The Protective Effect of Ascorbic Acid and Thiamine Supplementation against Damage Caused by Lead in the Testes of Mice. J. Huazhong. Univ. Sci. Technol. Med. Sci., 29: 2009, 68-72.

N. Batra, B. Nehru, and MP. Bansal, Reproductive Potential of Male Portan Rats Exposed to Various Levels of Lead Regard to Zinc Status. Br. J. Nutr., 91: 2004, 1887-1891.

N. Adhikari, N. Sinha, R. Narayan, and DK. Saxena, : Lead- induced Cell Death in Testes of Young Rats. J. Applied Toxicol., 21: 2001, 275-277.

I. Corpas, M. Castillo, M., Marquina, D. and MJ. Benito, Lead Intoxication in Gestational and Lactation Periods Alters the Development of Male Reproductive Organs. Ecotoxicology and Environmental Safety., 53: 2001, 259-266.

AJ. McMichael, GV. Vimpani, EF. Robertson, PA.Baghurst, PD. Clark, The Port Pirie Cohort Study: Maternal Blood Lead and Pregnancy Outcome. J. Epid. Comm. Health., 40: 1986, 18-25. Cell. Biol. Toxicol., 2: 1986, 283-292.

PC Hsu, CC. Hsu, MY. Liu, LY. Chen, and YL. Guo, Lead-induced Changes in Spermatozoa Function and Metabolism. J. Toxicol. Environ. Health A., 55: 1998, 45-64.

PC. Hsu, MY. Liu, CC. Hsu, LY. Chen, and YL. Guo, Lead Exposure Causes Generation of Reactive Oxygen Species and Functional Impairment in Rat Sperm. Toxicology., 122: 1997, 133-143.

RK. Dearth, JK. Hiney, V. Srivastava, W. Les Dees, GR. Bratton, Low levellead $(\mathrm{Pb})$ exposure during gestation and lactation: assessment of effects on pubertal development in Fisher 344 and Sprague-Dawley female rats. Life Sci. 74: 2004,1139-1148.

H. Lin, RS. Ge, GR. Chen, GX. Hu, L. Dong, QQ. Lian, DO. Hardy, CM. Sottas, XK. Li, MP. Hardy, Involvement of testicular growth factors in fetal Leydig cell aggregation after exposure to phthalate in utero. Proc. Natl. Acad. Sci. U. S. A. 105: $2008,7218-7222$. 